\title{
Democracy under Scrutiny
}

\section{A review of the monograph edited by Peter Smuk, Costs of Democracy, Gondolat, Budapest 2016}

\author{
ANNA BUDNIK*
}

'Democracy is the worst form of government, except for all those other forms that have been tried from time to time.' This famous quote by Winston Churchill reminds us that democracy is not an ideal form of the government but do societies ask themselves what the costs of democracy are and who in fact bears them?

This book shows that the costs of democracy take different forms. These are paid by the States, the governments and societies in specific countries and may also occur at the international level. The book shows that democratic standards and values are or at least should be universal. The infringement of these standards in one country frequently triggers problems in others. This concept is well presented in this book as the Authors of the chapters, who are academics from Eastern and Central Europe, show the problems of their own countries while some of them exemplify the issues in a broad and general context.

The book has two parts. The first section groups articles devoted to Principles and consists of articles from Erzsebet Kardos Kaponyi, Bence Kocev, Gabor Meszaros and Istvan Stumpf. The second part, titled Practices, contains thirteen essays that present detailed examples based on empirical or statistical data. All papers in the book are focused on the main subject of the book - the costs of democracy from a legal, economic, political, and sociological perspective. It is impossible to fully address the whole content of the book, so this review will focus upon the essays that are of special interest to the reviewer.

Erzsebet Kardos Kaponyi discusses the problem of the costs of human rights and starts with a presentation of the development of human rights at international and regional levels since the end of World War I. He rightly discerns this development, dating back to 1919, due to the increased role of the state and growing belief of governments at that time. The establishment of the United Nations after World War II is then discussed, the crucial acts accepted by that organization are presented in a concise way. It should be emphasised that he does not just give the bare facts, but also describes the process of setting up the international system of protecting human rights. The author then presents regional systems of human rights protection with the majority of attention upon two international organizations: The Council of Europe and the European Union. The considerations regarding the rule of law were particularly interesting as, the author correctly indicates, this rule is of special importance in the European Union. Admittedly, he does not deliberate on the essence of this principle, clearly due to the scope and dimension of the article, but he has touched upon a very current and crucial problem existing both in and outside Europe. This problem seems to be central in political and legal discussions, as the standing of that rule is essential for the preservation of human rights in all democracies. After brief reflections on the protections of human rights at national levels, the author finishes his paper with a presentation of the costs of functioning of human rights institutions. I very much

* Ph.D. LL.M. Assistant professor, Faculty of Law, University of Białystok, Poland. E-mail: a.budnik@uwb.edu.pl 
agree with the author's final statement that the cost of operation for these bodies is high but this is meaningless if we consider the human losses that could happen without these systems.

The second recommended article from the first part deals with populism. The author, as in the case of the previous articles, brought up a very real and concrete problem. Bence Kocsev shows that where there is democracy, there is populism, and he tries to present the reasons of thereof. He also attempts to conceptualize this notion. This chapter shows this task is not easy and the author presents definitions given by different scholars. However, he focuses on the 'New Populism' that is used to describe the phenomenon in the post-cold World War. The article explores also the problem of Euroscepticism in Central and Eastern Europe. The reviewer fully accept the diagnosis of problems presented by the author and agrees that one of these problems arises from people in these countries not believing that the current democratic institutions are working properly. The reader could have a feeling of a pessimistic and negative assessment of current political processes going throughout Europe and especially in Eastern Europe. However, surprisingly, the author, citing other scholars, describes some benefits that may come from populism, e.g., populism can be healing process for democratic institutions and processes and bring back those who felt marginalized to political practices. Populism, in the paper, as seen by the reviewer, is understood as a clash between the elite and the society and the paper suggests e-democracy and a dialogue between the academia-industry-government as a means to strengthen democracy.

I found this paper particularly important, it is truly vital considering what the costs of democracy are as discussions are happening whether we face the end of a liberal democracy across Europe and the United States. 2016, as some have pointed out, was particularly a period of movement that challenged and questioned liberal norms by populist parties and movements.

Gabor Meszaros indicates and justifies his main argument that the economic crisis along with political crises with violence and natural disasters, is the state of emergency that needs the State's intervention. He proves that to overcome this type of an emergency extra legal measures are possible.

Istvan Stumpf's paper on Constitutional Limitation of the State's intervention into property rights in Hungary also makes references to a problem of the financing crisis as well as the deliberations on the constitutional provisions and relevant verdicts of the Hungarian Constitutional Courts.

Part two of the book starts with a paper by Peter Darak that deals with the concept of property. He presents the origins and development of the property law and presents six verdicts of the European Court of Human Rights and compares the given judgments with the European Court of Justice and indicates the differences with respect to property law.

The question whether legislatures shall have fewer members is asked from time to time. It is a common presumption that a higher number of MPs results higher Parliamentary operation costs. Csaba Erdos in 'How Much Does the Operation of a Parliament Cost' shows that this is not always the case. The author's considerations are based on the recent reforms of the Hungarian Parliament. The number of Hungarian MPs is 199, according to the Act of 2011 on the election of MPs - a reduction by 187 . He compares different countries in his interesting study and presents the numbers of inhabitants per MP in some EU countries and USA. He concludes that there is no one model of the Parliament's size and structure. He also shows that reducing the number of MPs in Hungary did not lead to a 
reduction in parliamentary expenses as the Hungarian case was due to a pay-rise of MPs and officers and the increasing number of offices in the Office of the Parliament.

Artem Galushko compares different paths of decommunization in Hungary and Ukraine. He calls the transitional measures taken in Hungary such as lustration and retroactive justice that could be reference points for the Ukrainian state. Although he knows not all of the measures were satisfactory and has not completely fulfilled their goals, Ukraine should take these examples and draw positive conclusion for the late transitional justice.

Gergely G. Karacsony discusses public financing of higher education in Hungary. He presents different theories of funding higher education and gives reasons why public financing of this sector is seen beneficial for both the economy as well as the whole society. This paper is valuable especially for those who are interested in and responsible for higher education funding in their own countries. The article provides necessary information on the system of public financing in Hungary that can be used in the comparative studies especially in the Eastern European countries. He shows general ways of state funding and correctly links state funding of higher education institutions with their autonomy. It is shown, in a concise but very interesting way, how the law and the judgments of the Constitutional Court in Hungary define academic freedom and institutional autonomy with respect to funding of higher education.

Marina Lazareva in her paper presents relations between the Russian Constitutional Court and the European Court of Human Rights based on several cases and explains the reason for its tense character and tries to give a solution for this problem.

Andrey Skolkay touches upon one fundamental indication of democracy which is the free press and its political role in fighting corruption. His considerations are focused around the problem of the media coverage of corruption and especially of an uncovering fraud of the EU funds. The author pays special attention to the methodology of his research and discusses the correlation between freedom of the press and perception of corruption in the public sphere in six countries. He also explains the relations between the amount of the EU funds and the media coverage of the fraud in its allocation in given countries. The discoveries may be surprising and this paper is recommended for those who want to learn more about this subject.

Peter Smuk examines the problem of public financing of political parties and election campaigns from the constitutional law point of view. This study is interesting as it is based on examples of democratic systems from Western and Eastern countries including Hungary. From the outset of the paper, where the author is giving the definition of a political party and its functions, the author refers inter alia to the verdicts of the European Court of Human Rights and the German Constitutional Court. Later, he demonstrates the reasons for public financing of the political parties. The reviewer agrees with the author that public financing of these groups relates to the roles they play in a democratic society and the author underlines that both regular financing of political parties and campaign financing shall meet the same constitutional principles and gives a very interesting case study of the Hungarian instance.

Zsolt Spinder presents a brief assay on spreading of democratic standards through international conflicts. The author does not hide his opinion which is shared by the reviewer. Democracy is a system that shall be accepted voluntarily by the countries and this depends on time, culture and space. However, as Spinder admits in his paper, enforcement of democracy is usually only the slogan behind which economic interests are hidden. 
Peter Vaczi in his paper titled 'Costs of Democracy in Strasbourg' attempts to explain a high number of applications against Hungary to the European Court of Human Rights. He analyses the costs of the infringement of two principles of the European Convention of Human Rights: the principle that state authorities shall act and perform their duties within the reasonable time limit and principle that prohibits the torture.

Agnieszka Langowska and Karolina Agnieszka Wiśniewska wrote about economic costs of crimes and social costs of punishment, respectively. The book culminates with two short essays. Anna Korepina highlights the problem of the regulation of the conciliation procedure in Russia. Oksana Vasil'eva and Marina Milovanova paid attention to the problem of migration and its negative factors.

The monograph, as shown above, provides a variety of studies grouped around the main issue which is the costs of democracy. The main value of this book is that the authors are representatives of different sciences and experts in their fields. This work fully realizes its purpose and reveals that the costs of democracy cannot be solely understood in economic terms but there are legal, social and political aspects as well. All papers provide an excellent theoretical base to understand often uneasy problems that current democracies must face. This book is strongly recommended to anyone wishing to broaden their knowledge on the leitmotiv of the book. 